AGRITECH, Vol. 37, No. 1, Februari 2017, Hal. 38-47 DOI: http://dx.doi.org/10.22146/agritech.17007

ISSN 0216-0455 (Print), ISSN 2527-3825 (Online)

Tersedia online di https://jurnal.ugm.ac.id/agritech/

\title{
Kajian Metode dan Waktu Fermentasi Cairan Pulpa pada Perubahan Karakteristik Cuka Kakao
}

\author{
Study on The Method and Time of Pulp Watery Fermentation on The Characteristics Change of Cocoa Vinegar \\ G.P. Ganda Putra, Ni Made Wartini, Luh Putu Trisna Darmayanti
}

Fakultas Teknologi Pertanian, Universitas Udayana, Jl. Kampus Bukit Jimbaran, Badung, Bali 80361, Indonesia

Email:putu_gandaputra@yahoo.com

Submisi: 21 Agustus 2015; Penerimaan: 1 Maret 2016

\begin{abstract}
ABSTRAK
Cairan pulpa hasil samping fermentasi biji kakao berpotensi sebagai bahan baku pembuatan cuka kakao, tetapi kadar asam asetat yang dihasilkan relatif rendah. Untuk itu, perlu dilakukan upaya peningkatan kadar asam asetat antara lain dengan melakukan beberapa metode fermentasi lanjutan dengan variasi penambahan sumber karbon (gula dan alkohol) dan lama fermentasi. Tujuan penelitian ini adalah: (1) mengkaji pengaruh penambahan gula, alkohol dan lama fermentasi pada metode fermentasi lanjutan yang berbeda terhadap karakteristik cuka kakao dan (2) menetapkan metode fermentasi lanjutan dan lama fermentasi yang optimal untuk produksi cuka kakao dengan kadar asam asetat tertinggi. Metode fermentasi lanjutan yang dilakukan terdiri dari 3 metode yaitu: fermentasi alkohol dan asam asetat (2 tahap), fermentasi asam asetat (1 tahap), dan fermentasi tanpa inokulum (alami). Rancangan percobaan pada penelitian ini menggunakan Rancangan Acak Kelompok (RAK) faktorial 2 faktor pada metode fermentasi 2 tahap dan 1 tahap, serta RAK faktor tunggal pada fermentasi alami. Faktor I pada metode fermentasi 2 tahap yang menggunakan inokulum Saccharomyces cerevisiae dan Acetobacter aceti, adalah penambahan gula 4 konsentrasi (4, 6, 8, dan $10 \%$ ), dan pada metode fermentasi 1 tahap, yang menggunakan inokulum Acetobacter aceti, adalah penambahan alkohol 4 konsentrasi $(6,8,10$, dan $12 \%)$, sedangkan faktor II lama fermentasi $(0,5,10,15,20$, dan 25 hari). Sementara itu perlakuan lama fermentasi pada metode fermentasi alami sama seperti pada faktor II. Semua metode fermentasi dilakukan pada suhu kamar dalam 2 kelompok. Hasil penelitian menunjukkan bahwa: (1) karakteristik cuka kakao dan $\mathrm{OD}_{660}$ cairan pulpa dipengaruhi oleh perlakuan penambahan gula dan lama fermentasi serta interaksinya pada metode fermentasi 2 tahap dan oleh perlakuan penambahan alkohol dan lama fermentasi serta interaksinya pada fermentasi 1 tahap, serta oleh perlakuan lama fermentasi alami, dan (2) cuka kakao dengan kadar asam asetat tertinggi masing-masing dihasilkan pada fermentasi 2 tahap dengan penambahan gula cenderung $6 \%$ dalam waktu 25 hari (2,35\%), fermentasi 1 tahap dengan penambahan alkohol $10 \%$ dalam waktu 20 hari (3,37 \%), dan fermentasi alami dalam waktu 15 hari (2,65\%). Dengan demikian metode fermentasi 1 tahap dengan penambahan alkohol $10 \%$ menggunakan inokulum Acetobacter aceti dalam waktu 20 hari merupakan metode fermentasi lanjutan yang paling optimal untuk produksi cuka kakao.
\end{abstract}

Kata kunci: Cuka kakao; fermentasi; cairan pulpa

\begin{abstract}
The pulp water as byproduct of cocoa beans fermentation is potential to be used as a raw material for making cocoa vinegar, but unfortunately the content of acetic acid is relatively low. So that, it is necessary to increase the content of acetic acid, by performed further fermentation method with several addition of carbon sources (sugar and alcohol) and fermentation time. The purposes of this research were: (1) to study the effect of the addition of sugar, alcohol and fermentation time on different further fermentation method on the characteristics of cocoa vinegar and (2) to determine the optimal further fermentation method and fermentation time for the production of cocoa vinegar with
\end{abstract}


the highest content of acetic acid. Several fermentation methods were conducted by using three different methods e.g.the alcoholic and acetic acid fermentation (2 stages), acetic acid fermentation (1 stage), and fermentation without inoculum (natural). The experimental design of this study was using a factorial BRD two factors on the 2 stages and the 1 stage fermentation method, as well as the simple RBD on the natural fermentation. The first factor on the 2 stages fermentation methods used two different inoculum e.g. Saccharomyces cerevisiae and Acetobacter aceti, 4 different concentration of sugar (4, 6, 8 and $10 \%$ ), while on the 1 stage fermentation method used inoculum Acetobacter aceti, is 4 different concentrations of alcohol addition $(6,8,10$, and $12 \%)$, while the second factor is the same, namely 6 levels of fermentation time $(0,5,10,15,20$, and 25 days). Meanwhile, the treatment of fermentation time on the natural fermentation method was the same as the second factor. All methods of fermentation were performed at room temperature in 2 blocks/replications. The results showed that: 1) the characteristics of cocoa vinegar and $\mathrm{OD}_{660}$ of watery pulp were affected by : (1) the treatment of the sugar addition and fermentation time and their interaction on the 2 stages fermentation method by the treatment of the alcohol addition and fermentation time, their interaction on the 1 stage fermentation method, and by the treatment of fermentation time on the natural fermentation method, and (2) the cocoa vinegar with the highest content of acetic acid was produced on the 2 stages fermentation method by the addition of $6 \%$ sugar within 25 days $(2.35 \%)$, on the 1 stage fermentation method by the addition of $10 \%$ alcohol within 20 days $(3.37 \%)$, and on the natural fermentation method within 15 days $(2.65 \%)$, respectively. Our result showed that the 1 stage fermentation method with the addition of $10 \%$ alcohol using inoculum of Acetobacter acet $i$ within 20 days is the most optimal further fermentation method for the production of cocoa vinegar.

Keywords: Cocoa vinegar; fermentation; pulp watery

\section{PENDAHULUAN}

Tahapan pengolahan yang dianggap paling dominan mempengaruhi mutu hasil biji kakao kering adalah fermentasi (Alamsyah, 1991). Fermentasi biji kakao bertujuan untuk menghancurkan pulpa dan mengusahakan kondisi untuk terjadinya reaksi biokimia dalam keping biji, yang berperan bagi pembentukan prekursor cita rasa dan warna coklat, sebagai karakteristik khas kakao. Pulpa yang telah hancur akan mudah lepas dari biji, membentuk cairan pulpa (watery sweatings pulp) yang menetes keluar dari tumpukan biji. Cairan pulpa, sebagai hasil samping selama fermentasi biji kakao, diantaranya mengandung asam asetat, asam laktat, alkohol, dan gula. Asam-asam organik tersebut terbentuk dari fermentasi gula yang terkandung dalam pulpa biji kakao.

Pulpa biji kakao adalah selaput berlendir berwarna putih yang membungkus biji kakao, terdapat sekitar 25-30\% dari berat biji, diantaranya mengandung $82-87 \%$ air, $10-15$ $\%$ gula $(60 \%$ adalah sukrosa dan $39 \%$ campuran glukosa dan fruktosa), 2-3 \% pentosa, 1-3 \% asam sitrat, dan 1-1,5 $\%$ pektin, selain itu juga mengandung protein, asam amino, vitamin (terutama vitamin $\mathrm{C}$ ), dan mineral sehingga dapat menjadi media yang kaya untuk pertumbuhan mikroba (Diaset dkk., 2007; Schwan, 1998; Schwan and Wheals, 2004). Pulpa kakao diantaranya dapat digunakan untuk membuat selai, jelly, jus, serta dapat juga diolah menjadi minuman terfermentasi.

Selama fermentasi dihasilkan cairan pulpa $12-17 \%$ dari berat biji kakao (Ganda-Putra dkk., 2008; Ganda-Putra dkk.,
2012). Potensi cairan pulpa yang cukup besar tersebut selama ini hanya dibuang begitu saja disekitar tempat pengolahan, yang berdampak buruk dan mengotori lingkungan sekitarnya. Cairan pulpa sebenarnya dapat dimanfaatkan untuk membuat minuman terfermentasi, seperti asam cuka (Efendi, 2002), wine kakao, (Duarte dkk., 2010), dan minuman baru berbasis kakao kefir (Puerari dkk., 2012). Cuka kakao yang dihasilkan dari cairan pulpa kemungkinan besar mengandung komponen polifenol, sehingga akan dapat memberi efek fungsional yang bermanfaat positif bagi kesehatan, selain juga untuk meningkatkan nilai ekonomisnya. Asam cuka atau vinegar umumnya dapat digunakan sebagai bahan penyedap masakan atau sebagai minuman setelah dilakukan proses aging/penuaan. Sebagai kajian awal, telah dilakukan reka proses fermentasi biji kakao untuk mendapatkan gambaran riil tentang potensi cairan pulpa sebagai bahan baku cuka kakao, seperti penggunaan wadah fermentasi sistem "termos" (Ganda-Putra dan Wartini, 2014a) dan penambahan ragi tape (Ganda-Putra dan Wartini, 2014b). Namun dari proses pemurnian cairan pulpa yang telah dilakukan hanya menghasilkan distilat dengan kadar asam asetat relatif rendah, yaitu sekitar 0,2 - 0,4 \% (Ganda-Putra dkk., 2015). Untuk itu diperlukan kajian untuk meningkatkan kadar asam asetat dengan pengembangan metode fermentasi lanjutan terhadap substrat cairan pulpa hasil samping fermentasi biji kakao.

Pembuatan asam asetat diantaranya melibatkan dua tahap fermentasi, yaitu anaerob dan aerob. Fermentasi anaerob menghasilkan alkohol dengan inokulum yeast Saccharomyces cerevisiae, sedangkan fermentasi aerob 
untuk merubah alkohol menjadi asam asetat digunakan bakteri Acetobacter aceti. Pada fermentasi anaerob untuk menghasilkan alkohol, faktor penambahan sumber karbon (gula) sangat berpengaruh, seperti dilaporkan bahwa kadar alkohol tertinggi diperoleh dari substrat air kelapa dengan penambahan gula $16 \%$ (Dewi, 2012), sedangkan pada substrat nira kelapa dengan kadar gula 10 - $12 \%$ (Barlina dan Lay, 1994). Pada fermentasi 2 tahap untuk menghasilkan vinegar atau asam asetat, hasil optimal dari substrat sari buah nenas diperoleh pada penambahan gula $15 \%$ dan nutrisi untuk yeast dan bakteri berupa amonium sulfat $0,33 \mathrm{~g} / \mathrm{L}$ dan amonium posfat $0,05 \mathrm{~g} / \mathrm{L}$ dengan lama fermentasi anaerob 12 hari dan dilanjutkan dengan fermentasi aerob sampai 25 hari (Kwartiningsih dan Mulyati, 2005), sedangkan produk cuka salak terbaik dapat dihasilkan dengan fermentasi anaerob selama 10 hari menggunakan inokulum Saccharomyces cerevisiae $15 \%$ dan dilanjutkan selama 10 hari secara aerob pada suhu kamar dengan penambahan inokulum Acetobacter aceti (Zubaidah, 2010). Sementara itu, fermentasi 1 tahap untuk menghasilkan asam asetat dapat dilakukan dengan penambahan sumber karbon berupa alkohol. Fermentasi asam asetat dari air kelapa dapat dilakukan dengan penambahan alkohol $6 \%$ (Hidayat dkk., 1997) serta menggunakan media Hoyer dengan inokulum Acetobacter aceti $\mathrm{B}_{166}$ pada medium alkohol $6 \%$, pH awal 5,5, suhu $30^{\circ} \mathrm{C}$, dan waktu fermentasi 11 hari untuk menghasilkan asam asetat dengan konsentrasi tertinggi (Hardoyo dkk., 2007).

Penelitian ini diharapkan dapat lebih mengoptimalkan kajian dalam pemanfaatan cairan pulpa hasil samping fermentasi biji kakao menjadi produk cuka kakao atau vinegar. Kajian penerapan metode fermentasi asam asetat, selain mengacu kepada uraian di atas, juga mempertimbangkan karakteristik cairan pulpa yang sudah mengandung gula, alkohol, dan asam asetat. Untuk itu penelitian ini dilakukan dengan tujuan: (1) mengkaji pengaruh penambahan gula, alkohol dan lama fermentasi pada metode fermentasi lanjutan yang berbeda terhadap karakteristik cuka kakao dan (2) menetapkan metode fermentasi lanjutan dan lama fermentasi yang optimal untuk produksi cuka kakao dengan kadar asam asetat tertinggi.

\section{METODE PENELITIAN}

\section{Bahan dan Alat}

Bahan penelitian adalah cairan pulpa hasil samping fermentasi biji kakao selama 1-3 hari, yang diperoleh dari UUP Pasca Panen Kakao yang berlokasi di Desa Angkah, Kecamatan Selemadeg Barat, Kabupaten Tabanan, Bali. Bahan lain adalah gula, alkohol $96 \%$, isolat Saccharomyces cerevisiae FNCC 3049 dan Acetobacter aceti FNCC
0016 (diperoleh dari Pusat Studi Pangan dan Gizi UGM, Yogyakarta), pepton, ekstrak khamir, media Nutrient Agar/ NA (MRS Agar merk Oxoid), Nutrient Broth/NB (MRS Broth merk Oxoid) dan media Potato Dextrose Agar/PDA (merk Oxoid), diamonium hidrogen fosfat, Na-bisulfit, asam oksalat, indakator pp $1 \%$, glukosa anhidrat, serta bahan kimia untuk analisis sampel cuka kakao.

Peralatan yang digunakan diantaranya: wadah fermentasi (botol gallon dan toples plastik), timbangan (SHIMADZU ATY224), pengaduk magnetic (HP 220), water bath (P-SELECTA), pH meter (SCHOTT ${ }^{\circledR}$ ), spektrofotometer (GENESYS 10S UV-VIS), hand refraktometer (Portable Refractometer N-80), oven inkubator (MEMMERT), kertas saring, aerator aquarium, botol sampel, dan alat-alat gelas untuk analisis.

\section{Rancangan Percobaan}

Metode fermentasi lanjutan yang dilakukan terdiri dari 3 metode yaitu: fermentasi alkohol dan asam asetat (2 tahap), fermentasi asam asetat (1 tahap), dan fermentasi tanpa inokulum (alami). Rancangan percobaan menggunakan Rancangan Acak Kelompok (RAK) faktorial 2 faktor pada metode fermentasi 2 tahap dan 1 tahap, serta RAK faktor tunggal pada fermentasi alami, dengan faktor perlakuan sebagai berikut :

(1) Pada penelitian metode fermentasi 2 tahap, yang menggunakan inokulum Saccharomyces cerevisiae dan Acetobacter aceti faktor I adalah penambahan gula yang terdiri dari 4 konsentrasi (4, 6, 8 dan $10 \%$ ), sedangkan faktor II adalah lama fermentasi yang terdiri dari 6 taraf $(0,5,10,15,20$, dan 25 hari $)$.

(2) Pada penelitian metode fermentasi 1 tahap, yang menggunakan inokulum Acetobacter aceti faktor I adalah penambahan alkohol yang terdiri dari 4 konsentrasi $(6,8,10$, dan $12 \%)$, sedangkan faktor II adalah lama fermentasi yang terdiri dari $6 \operatorname{taraf}(0,5,10$, 15, 20, dan 25 hari).

(3) Pada penelitian metode fermentasi alami, faktor perlakuan adalah lama fermentasi yang terdiri dari 6 taraf $(0,5,10,15,20$, dan 25 hari $)$

Semua metode fermentasi dilakukan pada suhu kamar dan dikerjakan dalam 2 kelompok/ulangan. Data hasil pengamatan pada masing-masing metode fermentasi dianalisis dengan sidik ragam dan bila perlakauan berpengaruh nyata, dilanjutkan dengan uji DMRT $\left(p_{0.05}\right)$. Hasil ketiga riset ini kemudian dibandingkan secara deskriptif dan disajikan dalam bentuk grafik. 


\section{Pelaksanaan Penelitian}

\section{Pembuatan inokulum Saccharomyces cerevisiae}

Biakan murni Saccharomyces cerevisiae yang berumur 24 jam diinokulasikan dalam $100 \mathrm{~mL}$ media aktivasi dengan menggunakan jarum ose. Kultur dalam media cair aktivasi tersebut diinkubasi selama 24 jam pada suhu $37^{\circ} \mathrm{C}$. Kultur dalam media cair aktivasi ditambahkan ke dalam $1000 \mathrm{~mL}$ cairan pulpa, ditambah diamonium hidrogen fosfat $0,2 \%$ (b/v), dan sukrosa $12,5 \%$ (b/v), kemudian diinkubasi selama 24 jam pada suhu $37^{\circ} \mathrm{C}$ untuk selanjutnya digunakan sebagai inokulum dengan kerapatan sel pada $\mathrm{OD}_{660}$ sebesar 1,4 .

\section{Pembuatan inokulum Acetobacter aceti}

Sebanyak 13 g media Nutrient Broth/NB dilarutkan dalam $1 \mathrm{~L}$ aquades panas dan selanjutnya dilakukan sterilisasi menggunakan autoclaf pada suhu $121^{\circ} \mathrm{C}$ selama 15 menit. Biakan murni Acetobacter aceti yang berumur 48 jam sebanyak 2 ose diinokulasikan dalam $10 \mathrm{ml}$ media cair aktivasi secara aseptis kemudian diinkubasi selama 48 jam pada suhu $37^{\circ} \mathrm{C}$. Sebanyak $10 \mathrm{~mL}$ kultur dalam media cair aktivasi tersebut dimasukkan ke dalam erlenmeyer berisi $100 \mathrm{~mL}$ media cair aktivasi secara aseptis, diinkubasi selama 48 jam pada suhu $37{ }^{\circ} \mathrm{C}$. Kultur tersebut kemudian diinokulasikan ke dalam $1000 \mathrm{~mL}$ cairan pulpa beralkohol, diinkubasi selama 36 jam pada $37{ }^{\circ} \mathrm{C}$ untuk selanjutnya digunakan sebagai inokulum dengan kerapatan sel pada $\mathrm{OD}_{660}$ sebesar 1,3.

\section{Preparasi cairan pulpa}

Cairan pulpa hasil samping fermentasi biji kakao selama 1-3 hari disiapkan sebanyak $30 \mathrm{~L}$ disiapkan untuk masing-masing ulangan/kelompok. Cairan pulpa disaring dengan kain saring untuk memisahkan kotoran-kotoran yang ada. Selanjutnya dipisahkan sebanyak $12 \mathrm{~L}$ untuk fermentasi 2 tahap, $12 \mathrm{~L}$ untuk fermentasi 1 tahap, $3 \mathrm{~L}$ untuk fermentasi alami dan $3 \mathrm{~L}$ untuk pembuatan inokulum. Cairan pulpa untuk fermentasi 2 dan 1 tahap dipasteurisasi dalam panci pada suhu $65^{\circ} \mathrm{C}$ selama 30 menit untuk mematikan mikrobia awal.

\section{Fermentasi 2 tahap}

Cairan pulpa yang telah dipasteurisasi, dimasukkan dalam wadah fermentasi masing-masing sebanyak $3 \mathrm{~L}$ dan didinginkan sampai suhu $35{ }^{\circ} \mathrm{C}$ untuk mengkondisikan medium bagi khamir. Selanjutnya ditambahkan gula sesuai perlakuan dan inokulum Saccharomyces cerevisiae sebanyak $15 \%(\mathrm{v} / \mathrm{v})$ dan dilakukan fermentasi pada suhu kamar dalam kondisi anaerob selama 10 hari. Setelah itu ditambahkan inokulum Acetobacter aceti sebanyak $15 \%(\mathrm{v} / \mathrm{v})$ dan fermentasi dilanjutkan sampai 25 hari pada suhu kamar dalam kondisi aerob, dengan cara mengalirkan udara melalui selang plastik menggunakan aerator aquarium. Sampling cairan pulpa untuk pengamatan sesuai karakteristik cuka kakao, yaitu: asam asetat dengan titrasi, alkohol dengan piknometer, total gula dengan metode Nelson-Somogyi, dan total padatan terlarut (TPT) dengan refraktometer, menurut prosedur SNI01-4371-1996 dan $\mathrm{OD}_{660}$ pada waktu sesuai perlakuan lama fermentasi.

\section{Fermentasi 1 tahap}

Cairan pulpa yang telah dipasteurisasi, dimasukkan dalam wadah fermentasi masing-masing sebanyak 31 dan didinginkan sampai suhu $35{ }^{\circ} \mathrm{C}$ untuk mengkondisikan medium bagi bakteri. Selanjutnya ditambahan alkohol dengan konsentrasi sesuai perlakuan dan inokulum Acetobacter aceti ditambahkan sebanyak $15 \%$ (v/v), lalu difermentasi selama 25 hari pada suhu kamar dalam kondisi aerob, dengan cara mengalirkan udara melalui selang plastik menggunakan aerator aquarium. Sampling cairan pulpa juga dilakukan untuk pengatamatan sesuai karakteristik cuka kakao dan $\mathrm{OD}_{660}$ pada pada waktu sesuai perlakuan lama fermentasi.

\section{Fermentasi alami}

Cairan pulpa yang telah dipreparasi, dimasukkan dalam wadah fermentasi sebanyak 31 dan difermentasi selama 25 hari pada suhu kamar dalam kondisi aerob. Kondisi aerob dibuat dengan cara mengalirkan udara melalui selang plastik menggunakan aerator aquarium. Sampling cairan pulpa untuk pengatamatan sesuai karakteristik cuka kakao dan $\mathrm{OD}_{660}$ dilakukan pada waktu sesuai perlakuan lama fermentasi.

\section{HASIL DAN PEMBAHASAN}

\section{Fermentasi 2 Tahap}

Berdasarkan hasil uji Duncan, menunjukkan bahwa perlakuan penambahan gula berbeda nyata $(p<0,05)$ terhadap kadar alkohol, total gula, dan TPT; perlakuan waktu fermentasi berbeda nyata $(p<0,05)$ terhadap kadar asam asetat, alkohol, total gula, TPT dan $\mathrm{OD}_{660}$; serta interaksinya berpengaruh nyata $(p<0,05)$ terhadap kadar alkohol cuka kakao hasil fermentasi 2 tahap. Karakteristik cuka kakao hasil fermentasi 2 tahap selama 25 hari disajikan pada Tabel 1.

Dari Tabel 1 dapat diuraikan bahwa kadar asam asetat cuka kakao meningkat secara signifikan selama fermentasi. Penambahan gula $6 \%$ menghasilkan kadar asam asetat cenderung lebih tinggi dibandingkan dengan konsentrasi penamabahan gula yang lain. Waktu fermentasi sampai hari ke-10 tidak memberikan peningkatan kadar asam asetat yang signifikan, tetapi pada hari ke-15 dan seterusnya meningkat signifikan. Kondisi ini terjadi karena sampai hari ke-10 berlangsung fermentasi alkohol secara anaerob 
oleh yeast Saccharomyces cerevisiae, selanjutnya dengan penambahan bakteri Acetobacter aceti, terjadi perombakan alkohol menjadi asam asetat. Kenaikan kadar asam asetat saat fermentasi disebabkan pada kondisi fermentasi alkohol yang anaerob kemampuan Saccharomyces cerevisiae dalam menghasilkan alkohol maksimum sehingga pembentukan asam asetat juga tinggi (Zubaedah, 2010). Penambahan gula $6 \%$ menghasilkan kadar asam asetat cenderung lebih tinggi disebabkan pada kondisi tersebut Saccharomyces cerevisiae mampu berkembang lebih optimal, yang ditunjukkan oleh kadar alkohol yang lebih tinggi dari pada konsentrasi penambahan gula yang lain sehingga dihasilkan asam asetat juga lebih tinggi. Menurut Lu dkk. (1999), semakin tinggi konsentrasi alkohol pada medium maka jumlah asam asetat yang dihasilkan juga semakin tinggi. Penamabahan gula $6 \%$, dengan waktu minimal 20 hari dapat menghasilkan cuka kakao dengan kadar asam asetat lebih dari $2 \%$. Hasil tersebut sama dengan hasil survey oleh Kozaki dkk. (1998) pada proses pembuatan asam asetat secara tradisional di Indonesia dan Philipina, yaitu sekitar $2 \%$.
Kadar alkohol cuka kakao secara signifikan tertinggi pada penambahan gula $6 \%$ dengan waktu fermentasi 10 hari, sebesar 3,94\%. Penambahan gula $6 \%$ merupakan kondisi optimal bagi pertumbuhan Saccharomyces cerevisiae sehingga mampu menghasilkan alkohol tertinggi dibandingkan dengan perlakuan penambahan gula yang lain. Sampai dengan waktu fermentasi 10 hari pada semua perlakuan penambahan gula terjadi peningkatan kadar alkoholsecara signifikan, tetapi selanjutnya menurun drastis. Hal demikian terjadi karena setelah waktu fermentasi 10 hari aktivitas Saccharomyces cerevisiae dihambat dengan perubahan kondisi menjadi aerob disertai dengan penambahan inokulum Acetobacter aceti yang merombak alkohol menjadi asam asetat. Menurut Kozaki dkk. (1998), produk yang dihasilkan dari fermentasi gula, selain etanol dan gas $\mathrm{CO}_{2}$ adalah asam asetat, asam butirat, asam laktat, dan asetaldehida. Hal tersebut di atas pula yang mengakibatkan bahwa pada suatu saat, semakin lama fermentasi, kadar etanol yang dihasilkan akan optimum dan akhirnya akan menurun.

Tabel 1. Karakteristik cuka kakao hasil fermentasi 2 tahap selama 25 hari

\begin{tabular}{|c|c|c|c|c|c|c|c|c|}
\hline \multirow{2}{*}{$\begin{array}{l}\text { Karak- } \\
\text { teristik }\end{array}$} & \multirow{2}{*}{$\begin{array}{c}\text { Penambahan gula } \\
(\%, b / v)\end{array}$} & \multicolumn{6}{|c|}{ Lama fermentasi (hari) } & \multirow{2}{*}{ Rata-rata } \\
\hline & & 0 & 5 & 10 & 15 & 20 & 25 & \\
\hline \multirow{5}{*}{ 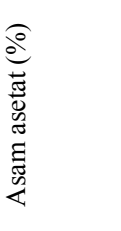 } & 4 & $0,57 \pm 0,37$ & $0,85 \pm 0,10$ & $1,08 \pm 0,08$ & $1,58 \pm 0,42$ & $1,65 \pm 0,22$ & $1,78 \pm 0,39$ & $1,25 \pm 0,49^{\mathrm{a}}$ \\
\hline & 6 & $0,58 \pm 0,36$ & $0,81 \pm 0,09$ & $1,04 \pm 0,14$ & $1,57 \pm 0,37$ & $2,15 \pm 0,74$ & $2,35 \pm 0,74$ & $1,41 \pm 0,73^{\mathrm{a}}$ \\
\hline & 8 & $0,58 \pm 0,36$ & $0,82 \pm 0,07$ & $1,02 \pm 0,08$ & $1,56 \pm 0,43$ & $1,58 \pm 0,33$ & $1,76 \pm 0,10$ & $1,22 \pm 0,48^{\mathrm{a}}$ \\
\hline & 10 & $0,56 \pm 0,37$ & $0,78 \pm 0,09$ & $0,96 \pm 0,09$ & $1,60 \pm 0,54$ & $1,65 \pm 0,49$ & $1,87 \pm 0,42$ & $1,24 \pm 0,54^{\mathrm{a}}$ \\
\hline & Rata-rata & $0,57^{\mathrm{e}} \pm 0,01$ & $0,82^{\mathrm{de}} \pm 0,03$ & $1,02^{\mathrm{cd}} \pm 0,049$ & $1,58^{\mathrm{b}} \pm 0,02$ & $1,76^{\mathrm{ab}} \pm 0,26$ & $1,94^{\mathrm{a}} \pm 0,28$ & \\
\hline \multirow{5}{*}{ 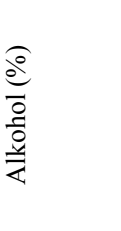 } & 4 & $1,28^{\mathrm{d}} \pm 0,24$ & $3,49^{\mathrm{ab}} \pm 0,73$ & $3,04^{b} \pm 0,81$ & $0,92^{\mathrm{d}} \pm 0,06$ & $0,00^{\mathrm{e}} \pm 0,00$ & $0,00^{\mathrm{e}} \pm 0,00$ & $1,45 \pm 1,50$ \\
\hline & 6 & $0,74^{\mathrm{d}} \pm 0,06$ & $3,89^{\mathrm{a}} \pm 0,76$ & $3,94^{\mathrm{a}} \pm 0,43$ & $1,00^{\mathrm{d}} \pm 0,21$ & $0,00^{\mathrm{e}} \pm 0,00$ & $0,00^{\mathrm{e}} \pm 0,00$ & $1,59 \pm 1,84$ \\
\hline & 8 & $0,89^{\mathrm{d}} \pm 0,02$ & $2,20^{\mathrm{c}} \pm 0,28$ & $2,84^{\mathrm{bc}} \pm 0,23$ & $0,82^{\mathrm{d}} \pm 0,20$ & $0,00^{\mathrm{e}} \pm 0,00$ & $0,00^{\mathrm{e}} \pm 0,00$ & $1,12 \pm 1,16$ \\
\hline & 10 & $0,93^{\mathrm{d}} \pm 0,04$ & $2,20^{c} \pm 0,28$ & $2,94^{\mathrm{b}} \pm 0,57$ & $0,75^{\mathrm{d}} \pm 0,15$ & $0,00^{\mathrm{e}} \pm 0,00$ & $0,00^{\mathrm{e}} \pm 0,00$ & $1,14 \pm 1,20$ \\
\hline & Rata-rata & $0,96 \pm 0,23$ & $2,94 \pm 0,89$ & $3,19 \pm 0,48$ & $0,87 \pm 0,11$ & $0,00 \pm 0,00$ & $0,00 \pm 0,00$ & \\
\hline \multirow{5}{*}{ 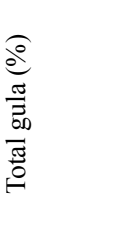 } & 4 & $6,01 \pm 0,28$ & $5,66 \pm 1,52$ & $3,83 \pm 0,57$ & $2,54 \pm 0,40$ & $1,07 \pm 0,10$ & $0,56 \pm 0,38$ & $3,28 \pm 2,29^{c}$ \\
\hline & 6 & $7,83 \pm 1,72$ & $7,38 \pm 1,17$ & $5,25 \pm 0,60$ & $3,39 \pm 1,62$ & $2,17 \pm 1,10$ & $0,53 \pm 0,00$ & $4,43 \pm 2,91^{\mathrm{b}}$ \\
\hline & 8 & $9,55 \pm 1,97$ & $8,39 \pm 2,65$ & $6,28 \pm 0,47$ & $4,01 \pm 1,73$ & $2,41 \pm 1,24$ & $0,99 \pm 0,62$ & $5,27 \pm 3,38^{\mathrm{ab}}$ \\
\hline & 10 & $11,46 \pm 1,20$ & $10,12 \pm 1,97$ & $7,72 \pm 0,06$ & $4,57 \pm 2,74$ & $3,05 \pm 1,48$ & $0,97 \pm 0,33$ & $6,32 \pm 4,13^{\mathrm{a}}$ \\
\hline & Rata-rata & $8,71^{a} \pm 2,33$ & $7,89^{\mathrm{a}} \pm 1,87$ & $5,77^{\mathrm{b}} \pm 1,64$ & $3,63^{\mathrm{c}} \pm 0,87$ & $2,18^{\mathrm{d}} \pm 0,82$ & $0,76^{\mathrm{e}} \pm 0,25$ & \\
\hline \multirow{5}{*}{ 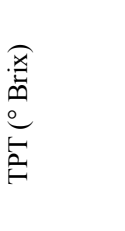 } & 4 & $9,80 \pm 0,42$ & $9,28 \pm 1,10$ & $7,50 \pm 0,71$ & $6,25 \pm 1,77$ & $5,00 \pm 0,00$ & $4,13 \pm 0,18$ & $6,99 \pm 2,28^{c}$ \\
\hline & 6 & $10,30 \pm 0,28$ & $10,10 \pm 0,14$ & $9,75 \pm 0,35$ & $8,00 \pm 1,41$ & $5,75 \pm 1,77$ & $4,25 \pm 0,35$ & $8,03 \pm 2,53^{b}$ \\
\hline & 8 & $10,95 \pm 0,78$ & $10,23 \pm 0,18$ & $9,88 \pm 0,18$ & $8,25 \pm 1,06$ & $6,50 \pm 2,83$ & $4,50 \pm 0,71$ & $8,38 \pm 2,48^{a b}$ \\
\hline & 10 & $11,53 \pm 1,38$ & $10,35 \pm 0,21$ & $10,10 \pm 0,14$ & $8,50 \pm 0,71$ & $6,25 \pm 2,47$ & $4,75 \pm 1,06$ & $8,58 \pm 2,62^{\mathrm{a}}$ \\
\hline & Rata-rata & $10,64^{\mathrm{a}} \pm 0,75$ & $9,99^{\mathrm{ab}} \pm 0,49$ & $9,31^{\mathrm{b}} \pm 1,21$ & $7,75^{\mathrm{c}} \pm 1,02$ & $5,88^{\mathrm{d}} \pm 0,66$ & $4,41^{\mathrm{e}} \pm 0,28$ & \\
\hline \multirow{5}{*}{ 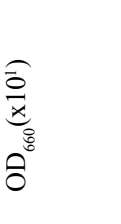 } & 4 & $0,45 \pm 0,00$ & $0,26 \pm 0,05$ & $0,40 \pm 0,00$ & $0,46 \pm 0,05$ & $0,34 \pm 0,04$ & $0,24 \pm 0,03$ & $0,356 \pm 0,095^{\mathrm{a}}$ \\
\hline & 6 & $0,41 \pm 0,03$ & $0,30 \pm 0,01$ & $0,40 \pm 0,01$ & $0,47 \pm 0,01$ & $0,42 \pm 0,02$ & $0,31 \pm 0,03$ & $0,382 \pm 0,065^{\mathrm{a}}$ \\
\hline & 8 & $0,42 \pm 0,00$ & $0,35 \pm 0,02$ & $0,34 \pm 0,02$ & $0,52 \pm 0,07$ & $0,39 \pm 0,11$ & $0,30 \pm 0,04$ & $0,385 \pm 0,075^{a}$ \\
\hline & 10 & $0,41 \pm 0,02$ & $0,33 \pm 0,03$ & $0,34 \pm 0,05$ & $0,47 \pm 0,01$ & $0,34 \pm 0,03$ & $0,29 \pm 0,01$ & $0,363 \pm 0,068^{\mathrm{a}}$ \\
\hline & Rata-rata & $0,42^{b} \pm 0,02$ & $0,31^{\mathrm{d}} \pm 0,04$ & $0,37^{\mathrm{c}} \pm 0,03$ & $0,48^{\mathrm{a}} \pm 0,03$ & $0,37^{\mathrm{c}} \pm 0,04$ & $0,28^{\mathrm{d}} \pm 0,03$ & \\
\hline
\end{tabular}

${ }^{*}$ Huruf berbeda di belakang nilai rata-rata menunjukkan beda nyata pada uji DMRT $\left(p_{0.05}\right)$ 
Kadar total gula cuka kakao mengalami penurunan secara signifikan selama fermentasi dan penambahan gula dengan konsentrasi lebih rendah menyebabkan kadar total gula juga lebih rendah. Penurunan total gula selama fermentasi terjadi akibat aktivitas Saccharomyces cerevisiae yang merombak gula menjadi alkohol, selanjutnya dirombak lagi menjadi asam asetat oleh Acetobacter aceti. Selain itu, pada kondisi fermentasi anaerob juga digunakan oleh mikroorganisme sebagai sumber karbon. Menurut Rahman (1992), pada fermentasi asam asetat, sumber karbon (biasanya glukosa) dioksidasi menjadi $\mathrm{CO}_{2}$ dan $\mathrm{H}_{2} \mathrm{O}$. Hal demikian menyebabkan kadar gula makin rendah dengan makin lama waktu fermentasi.

Sejalan dengan kadar total gula, kadar total padatan terlarut (TPT) pada cuka kakao juga mengalami perubahan yang sama. Hal demikian terjadi karena senyawa-senyawa sebagai komponen yang terlarut, seperti gula, garam-garam dan senyawa terlarut dalam air, mengalami perombakan. Penurunan total padatan terlarut selama fermentasi diduga disebabkan selama proses fermentasi berlangsung, gula yang merupakan komponen padatan terlarut yang dominan dalam medium disamping pigmen, vitamin, dan mineral, dimetabolisme oleh yeast menjadi alkohol dan $\mathrm{CO}_{2}$, serta dimanfaatkan oleh bakteri sebagai sumber karbon. Hal ini diperkuat dengan pernyataan Reed and Nagodawithana (1991), bahwa terjadi penurunan total padatan terlarut selama proses fermentasi oleh yeast dan bakteri.

Perkembangan kerapatan sel (populasi) mikroba pada sampel cuka kakaoyang direpresentasikan sebagai $\mathrm{OD}_{660}$, pada fermentasi hari ke-5 terjadi penurunan secara signifikan dibandingkan awal fermentasi, kemudian meningkat sampai hari ke-15, tetapi selanjutnya menurun lagi. Sedangkan perlakuan penambahan gula secara rata-rata tidak memberikan perbedaan yang signifikan terhadap populasi mikroba. Penurunan populasi hari ke-5 kemungkinan masih dalam kondisi adaptasi dan berkembang lagi mulai hari ke-10. Selanjutnya peningkatan populasi hari ke-15 dapat disebabkan oleh penambahan inokulum Acetobacter aceti pada hari ke-10, selain inokulum Saccharomyces cerevisiae yang ditambahkan pada awal fermentasi. Menurut Takrama dkk. (2015), Saccharomyces cerevisiae merupakan yeast yang potensial dalam produksi etanol dari substrat cairan pulpa kakao, sementara itu Effendi (2002), mengemukkan bahwa bakteri Acetobacter aceti memiliki kenetika proses produksi asam asetat yang optimal dari etanol hasil fermentasi cairan pulpa kakao. Kondisi ini menyebabkan yeast dan bakteri yang ditambahkan dapat tumbuh dan berkembang, yang ditunjukkan oleh peningkatan populasi selama fermentasi.

\section{Fermentasi 1 Tahap}

Berdasarkan hasil uji Duncan, menunjukkan bahwa perlakuan penambahan alkohol berbeda nyata $(p<0,05)$ terhadap kadar asam asetat dan alkohol; perlakuan waktu fermentasi berbeda nyata $(p<0,05)$ terhadap kadar asam asetat, alkohol, total gula, TPT dan $\mathrm{OD}_{66}$; serta interaksinya berbeda nyata $(p<0,05)$ terhadap kadar alkohol cuka kakao hasil metode fermentasi 1 tahap. Karakteristik cuka kakao hasil metode fermentasi 1 tahap selama 25 hari disajikan pada Tabel 2.

Dari Tabel 2 dapat diuraikan bahwa kadar asam asetat cuka kakao meningkat secara signifikan sampai fermentasi hari ke-20, mencapai tertinggi $3,34 \%$, tetapi kemudian menurun. Penambahan alkohol $10 \%$ menghasilkan kadar asam asetat secara signifikan lebih tinggi dibandingkan dengan konsentrasi penambahan alkohol yang lain. Peningkatan kadar asam asetat sampai fermentasi hari ke-20 menunjukkan bahwa aktivitas perombakan alkohol menjadi asam asetat oleh bakteri Acetobacter aceti berlangsung optimal, tetapi fermentasi lebih lama diduga asam asetat yang telah terbentuk dirombak lebih lanjut sehingga kadarnya menurun. Hal demikian dijelaskan oleh Rahman (1992), bahwa pada fermentasi lebih lanjut asam asetat yang telah terbentuk dirombak menjadi $\mathrm{H}_{2} \mathrm{O}$ dan $\mathrm{CO}_{2}$. Peningkatan konsentrasi alkohol yang ditambahkan sampai $10 \%$ menghasilkan kadar asam asetat yang terus meningkat, tetapi pada konsentrasi lebih tinggi menurun lagi. Hal demikian terjadi karena semakin tinggi konsentrasi alkohol maka kadar asam asetat yang dihasilkan juga semakin tinggi, tetapi peningkatan konsentrasi alkohol lebih lanjut justru akan menghambat pertumbuhan bakteri Acetobacter aceti. Hotmaka dan Ebner (1995), menyatakan bahwa kadar alkohol yang baik digunakan sebagai substrat dalam fermentasi asam asetat adalah sebesar 5-7\%. Sementara itu, perlakuan penambahan alkohol 10 dan $12 \%(\mathrm{v} / \mathrm{v})$ diperoleh kadar alkohol awal substrat sebesar 4,68 dan 6,48\% (Tabel 2), sehingga perlakuan tersebut dapat menghasilkan cuka kakao dengan kadar asam asetat relatif lebih tinggi.

Makin lama waktu fermentasi dan makin rendah konsentrasi penambahan alkohol menghasilkan cuka kakao dengan kadar alkohol makin rendah serta tidak terdeteksi lagi pada fermentasi hari ke-25 untuk semua perlakuan penambahan alkohol. Hal demikian terjadi karena semakin lama waktu fermentasi perombakan alkohol oleh bakteri Acetobacter aceti berlangsung lebih baik. Umumnya perombakan suatu senyawa diantaranya dipengaruhi oleh waktu, sehingga makin lama fermentasi kadar alkohol cuka kakao makin rendah, bahkan tidak terdeteksi pada hari ke-25. Sementara itu, terkait dengan perlakuan penambahan alkohol, semakin rendah konsentrasi alkohol yang ditambahkan akan makin cepat dirombak sehingga rata-rata kadar alkohol pada cuka kakao menjadi lebih rendah. Selama proses fermentasi asam asetat, Acetobacter aceti merombak alkohol menjadi asam asetat sehingga jumlah alkohol awal akan berkurang, 
Tabel 2. Karakteristik cuka kakao hasil fermentasi 1 tahap selama 25 hari

\begin{tabular}{|c|c|c|c|c|c|c|c|c|}
\hline \multirow{2}{*}{$\begin{array}{l}\text { Karak- } \\
\text { teristik }\end{array}$} & \multirow{2}{*}{$\begin{array}{c}\text { Penambahan alkohol } \\
(\%, \mathrm{v} / \mathrm{v})\end{array}$} & \multicolumn{6}{|c|}{ Lama fermentasi (hari) } & \multirow[t]{2}{*}{ Rata-rata } \\
\hline & & 0 & 5 & 10 & 15 & 20 & 25 & \\
\hline \multirow{5}{*}{ 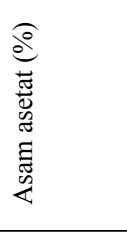 } & 6 & $0,96 \pm 0,22$ & $1,36 \pm 0,57$ & $1,95 \pm 0,20$ & $2,16 \pm 0,06$ & $2,45 \pm 0,23$ & $1,92 \pm 0,25$ & $1,80 \pm 0,54^{b}$ \\
\hline & 8 & $1,01 \pm 0,26$ & $1,34 \pm 0,57$ & $2,10 \pm 0,76$ & $2,14 \pm 0,27$ & $2,47 \pm 0,54$ & $1,99 \pm 0,08$ & $1,84 \pm 0,55^{\mathrm{b}}$ \\
\hline & 10 & $0,99 \pm 0,25$ & $1,16 \pm 0,45$ & $2,60 \pm 0,54$ & $2,82 \pm 0,43$ & $3,37 \pm 0,14$ & $2,84 \pm 0,36$ & $2,30 \pm 0,98^{\mathrm{a}}$ \\
\hline & 12 & $1,01 \pm 0,25$ & $1,22 \pm 0,32$ & $2,06 \pm 0,93$ & $2,51 \pm 0,70$ & $2,80 \pm 0,85$ & $2,07 \pm 0,22$ & $1,94 \pm 0,71^{\mathrm{b}}$ \\
\hline & Rata-rata & $0,99^{c} \pm 0,02$ & $1,27^{c} \pm 0,10$ & $2,18^{b} \pm 0,29$ & $2,41^{b} \pm 0,32$ & $2,77^{a} \pm 0,43$ & $2,20^{b} \pm 0,43$ & \\
\hline \multirow{5}{*}{$\begin{array}{l}\frac{0}{0} \\
\frac{0}{0} \\
\frac{0}{0} \\
\frac{o}{2}\end{array}$} & 6 & $2,72^{\mathrm{de}} \pm 0,61$ & $0,73^{\mathrm{fgh}} \pm 0,62$ & $0,30^{\mathrm{h}} \pm 0,29$ & $0,11^{\mathrm{h}} \pm 0,15$ & $0,00^{i} \pm 0,00$ & $0,00^{\mathrm{i}} \pm 0,00$ & $0,64 \pm 1,05$ \\
\hline & 8 & $3,78^{c} \pm 0,08$ & $1,40^{\mathrm{f}} \pm 0,83$ & $0,50^{\mathrm{gh}} \pm 0,53$ & $0,36^{\mathrm{h}} \pm 0,50$ & $0,06^{\mathrm{hi}} \pm 0,09$ & $0,00^{i} \pm 0,00$ & $1,02 \pm 1,44$ \\
\hline & 10 & $4,68^{b} \pm 0,86$ & $2,39^{\mathrm{e}} \pm 0,56$ & $0,83^{\mathrm{fgh}} \pm 0,52$ & $0,45^{\mathrm{gh}} \pm 0,52$ & $0,18^{\mathrm{h}} \pm 0,25$ & $0,00^{i} \pm 0,00$ & $1,42 \pm 1,81$ \\
\hline & 12 & $6,48^{\mathrm{a}} \pm 0,05$ & $3,10^{\mathrm{d}} \pm 0,38$ & $1,32^{\mathrm{fg}} \pm 0,23$ & $0,74^{\mathrm{fgh}} \pm 0,37$ & $0,40^{\mathrm{h}} \pm 0,23$ & $0,00^{i} \pm 0,00$ & $2,01 \pm 2,44$ \\
\hline & Rata-rata & $4,41 \pm 1,59$ & $1,90 \pm 1,05$ & $0,74 \pm 0,44$ & $0,41 \pm 0,26$ & $0,18 \pm 0,18$ & $0,00 \pm 0,00$ & \\
\hline \multirow{5}{*}{$\begin{array}{l}\frac{\partial}{\partial} \\
\frac{\pi}{\vec{b}} \\
\frac{\sigma_{0}}{\pi} \\
\stackrel{\pi}{0}\end{array}$} & 6 & $7,88 \pm 4,56$ & $7,16 \pm 3,92$ & $5,89 \pm 2,79$ & $4,88 \pm 2,03$ & $4,09 \pm 1,61$ & $2,73 \pm 1,71$ & $5,44 \pm 1,93^{\mathrm{a}}$ \\
\hline & 8 & $7,62 \pm 3,95$ & $7,16 \pm 3,80$ & $5,62 \pm 2,31$ & $5,08 \pm 2,11$ & $3,43 \pm 1,20$ & $2,88 \pm 1,55$ & $5,30 \pm 1,91^{\mathrm{a}}$ \\
\hline & 10 & $8,38 \pm 4,87$ & $7,52 \pm 4,72$ & $6,13 \pm 4,28$ & $4,65 \pm 2,24$ & $3,68 \pm 1,84$ & $1,93 \pm 1,34$ & $5,38 \pm 2,43^{\mathrm{a}}$ \\
\hline & 12 & $8,36 \pm 4,29$ & $7,74 \pm 3,65$ & $6,58 \pm 3,29$ & $5,15 \pm 1,73$ & $3,68 \pm 2,07$ & $2,00 \pm 0,34$ & $5,59 \pm 2,45^{\mathrm{a}}$ \\
\hline & Rata-rata & $8,06^{a} \pm 0,37$ & $7,39^{\mathrm{a}} \pm 0,29$ & $6,05^{\mathrm{bc}} \pm 0,41$ & $4,94^{\mathrm{cd}} \pm 0,22$ & $3,72^{\mathrm{d}} \pm 0,27$ & $2,38^{\mathrm{e}} \pm 0,49$ & \\
\hline \multirow{5}{*}{ 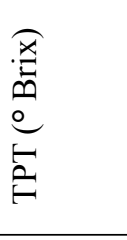 } & 6 & $6,75 \pm 1,77$ & $6,38 \pm 1,24$ & $5,50 \pm 0,71$ & $5,13 \pm 0,88$ & $5,00 \pm 0,71$ & $4,13 \pm 0,18$ & $5,48 \pm 0,96^{\mathrm{a}}$ \\
\hline & 8 & $7,50 \pm 2,12$ & $6,50 \pm 1,41$ & $5,63 \pm 0,88$ & $5,50 \pm 0,71$ & $4,75 \pm 0,35$ & $4,38 \pm 0,18$ & $5,71 \pm 1,15^{\mathrm{a}}$ \\
\hline & 10 & $7,50 \pm 2,12$ & $7,00 \pm 0,71$ & $6,00 \pm 0,71$ & $5,50 \pm 0,71$ & $4,75 \pm 0,35$ & $4,00 \pm 0,71$ & $5,79 \pm 1,33^{\mathrm{a}}$ \\
\hline & 12 & $7,75 \pm 1,77$ & $7,13 \pm 0,88$ & $6,00 \pm 0,71$ & $5,50 \pm 0,71$ & $5,00 \pm 0,00$ & $4,63 \pm 0,18$ & $6,00 \pm 1,22^{\mathrm{a}}$ \\
\hline & Rata-rata & $7,38^{a} \pm 0,43$ & $6,75^{a} \pm 0,37$ & $5,78^{\mathrm{bc}} \pm 0,26$ & $5,41^{\mathrm{cd}} \pm 0,19$ & $4,88^{\mathrm{de}} \pm 0,14$ & $4,28^{e} \pm 0,28$ & \\
\hline \multirow{5}{*}{$\begin{array}{l}\underset{\hat{\sigma}}{x} \\
\underset{0}{0} \\
0\end{array}$} & 6 & $0,41 \pm 0,08$ & $0,37 \pm 0,01$ & $0,47 \pm 0,15$ & $0,51 \pm 0,18$ & $0,38 \pm 0,04$ & $0,35 \pm 0,02$ & $0,41 \pm 0,06^{\mathrm{a}}$ \\
\hline & 8 & $0,43 \pm 0,01$ & $0,37 \pm 0,02$ & $0,45 \pm 0,12$ & $0,43 \pm 0,12$ & $0,50 \pm 0,11$ & $0,51 \pm 0,11$ & $0,45 \pm 0,05^{\mathrm{a}}$ \\
\hline & 10 & $0,44 \pm 0,02$ & $0,39 \pm 0,02$ & $0,46 \pm 0,06$ & $0,50 \pm 0,01$ & $0,52 \pm 0,06$ & $0,55 \pm 0,12$ & $0,48 \pm 0,06^{\mathrm{a}}$ \\
\hline & 12 & $0,40 \pm 0,03$ & $0,35 \pm 0,03$ & $0,45 \pm 0,05$ & $0,47 \pm 0,06$ & $0,53 \pm 0,14$ & $0,53 \pm 0,07$ & $0,46 \pm 0,07^{\mathrm{a}}$ \\
\hline & Rata-rata & $0,42^{\mathrm{ab}} \pm 0,02$ & $0,37^{b} \pm 0,02$ & $0,46^{\mathrm{a}} \pm 0,01$ & $0,48^{\mathrm{a}} \pm 0,04$ & $0,48^{\mathrm{a}} \pm 0,07$ & $0,48^{\mathrm{a}} \pm 0,09$ & \\
\hline
\end{tabular}

${ }^{*}$ Huruf berbeda di belakang nilai rata-rata menunjukkan beda nyata pada uji DMRT $\left(\mathrm{P}_{0.05}\right)$

seperti dikemukakan Daulay dan Rahman (1992), bahwa alkohol merupakan medium bakteri asam asetat untuk hidup dan diubah menjadi asam asetat. Apabila kadar alkohol substrat sesuai untuk pertumbuhan Acetobacter aceti, maka substrat beralkohol sebagian besar akan dioksidasi menjadi asam asetat.

Kadar total gula cuka kakao mengalami penurunan secara signifikan selama fermentasi, tetapi tidak berbeda secara signifikan akibat penambahan alkohol pada konsentrasi yang berbeda. Penurunan total gula selama fermentasi, dari rata-rata sebesar 8,06\% menjadi 2,38\% setelah fermentasi 25 hari, terjadi akibat perombakan gula oleh bakteri, terutama sebagai sumber karbon. Menurut Rahman (1992), pada fermentasi asam asetat sumber karbon (biasanya glukosa) dioksidasi menjadi $\mathrm{CO}_{2}$ dan $\mathrm{H}_{2} \mathrm{O}$.

Pada fermentasi asam asetat, kadar total padatan terlarut (TPT) pada cuka kakao juga mengalami perubahan yang sama seperti kadar total gula. Penurunan total padatan terlarut selama fermentasi diduga disebabkan selama proses fermentasi berlangsung, gula yang merupakan komponen padatan terlarut yang dominan dalam medium, disamping pigmen, vitamin, dan mineral, dimanfaatkan oleh bakteri sebagai sumber karbon (Rahman, 1992). Selain itu diperkuat oleh Reed and Nagodawithana (1991), bahwa terjadi penurunan total padatan terlarut selama proses fermentasi oleh bakteri maupun juga yeast.

Pada perlakuan lama fermentasi, perkembangan kerapatan sel (populasi) bakteri pada sampel cuka kakao yang direpresentasikan sebagai $\mathrm{OD}_{660}$, hari ke-5 terjadi penurunan dibandingkan awal fermentasi, tetapi selanjutnya terjadi peningkatan dari hari ke-10 sampai ke-25. Sedangkan perlakuan penambahan alkohol secara rata-rata tidak memberikan perbedaan yang signifikan terhadap populasi mikroba. Populasi bakteri yang mengalami penurunan pada hari ke-5 kemungkinan masih dalam kondisi adaptasi.

Sementara itu peningkatan populasi dari hari ke-10 sampai ke-25, terutama pada perlakuan penambahan alkohol 10 dan $12 \%(\mathrm{v} / \mathrm{v})$, terjadi karena kondisi fermentasi tersebut 
Tabel 3. Karakteristik cuka kakao hasil fermentasi alami dalam kondisi aerob

\begin{tabular}{cccccc}
\hline \multirow{2}{*}{ Lama fermentasi (hari) } & \multicolumn{5}{c}{ Karakteristik } \\
\cline { 2 - 5 } & Asam asetat (\%) & Alkohol (\%) & Total gula (\%) & $\begin{array}{c}\text { TPT } \\
\left({ }^{\circ} \text { Brix }\right)\end{array}$ & OD $_{660}\left(\times 10^{1}\right)$ \\
\hline 0 & $0,87 \pm 0,32^{\mathrm{c}}$ & $1,60 \pm 0,19^{\mathrm{a}}$ & $5,59 \pm 0,53^{\mathrm{a}}$ & $6,50 \pm 0,71^{\mathrm{a}}$ & $0,173 \pm 0,025^{\mathrm{e}}$ \\
5 & $1,68 \pm 0,05^{\mathrm{b}}$ & $1,08 \pm 0,01^{\mathrm{b}}$ & $4,56 \pm 0,86^{\mathrm{ab}}$ & $5,25 \pm 0,35^{\mathrm{b}}$ & $0,276 \pm 0,013^{\mathrm{bc}}$ \\
10 & $2,39 \pm 0,07^{\mathrm{a}}$ & $0,74 \pm 0,08^{\mathrm{c}}$ & $4,20 \pm 0,65^{\mathrm{abc}}$ & $4,75 \pm 0,35^{\mathrm{c}}$ & $0,426 \pm 0,010^{\mathrm{a}}$ \\
15 & $2,65 \pm 0,22^{\mathrm{a}}$ & $0,43 \pm 0,11^{\mathrm{d}}$ & $3,42 \pm 0,24^{\mathrm{bcd}}$ & $4,00 \pm 0,02^{\mathrm{d}}$ & $0,261 \pm 0,007^{\mathrm{c}}$ \\
20 & $1,67 \pm 0,55^{\mathrm{b}}$ & $0,00 \pm 0,00^{\mathrm{e}}$ & $2,80 \pm 0,78^{\mathrm{cd}}$ & $3,50 \pm 0,01^{\mathrm{e}}$ & $0,212 \pm 0,012^{\mathrm{d}}$ \\
25 & $1,42 \pm 0,14^{\mathrm{b}}$ & $0,00 \pm 0,00^{\mathrm{e}}$ & $2,23 \pm 0,11^{\mathrm{d}}$ & $3,25 \pm 0,07^{\mathrm{e}}$ & $0,166 \pm 0,008^{\mathrm{e}}$ \\
\hline
\end{tabular}

${ }^{*}$ Huruf berbeda di belakang nilai rata-rata menunjukkan beda nyata pada uji DMRT $\left(p_{0.05}\right)$

sesuai untuk pertumbuhan bakteri Acetobacter aceti. Pada perlakuan penambahan alkohol tersebut diperoleh kadar alkohol awal substrat sebesar 4,68 dan 6,48 \% (Tabel 2). Hal demikian sejalan dengan temuan Hotmaka and Ebner (1995), yang menyatakan bahwa kadar alkohol yang baik sebagai substrat fermentasi asam asetat adalah sebesar 5-7 $\%$. Hal ini ditunjukkan pula oleh aktivitas bakteri tersebut dalam merombak alkohol menjadi asam asetat yang terus meningkat.

\section{Fermentasi Alami}

Berdasarkan hasil uji Duncan, menunjukkan bahwa perlakuan lama fermentasi berbeda nyata $(p<0,05)$ terhadap kadar asam asetat, alkohol, total gula, TPT dan $\mathrm{OD}_{660}$ cuka kakao hasil fermentasi alami. Karakteristik cuka kakao hasil fermentasi alami (tanpa inokulum) dalam kondisi aerob (Tabel 3), menunjukkan bahwa kadar asam asetat meningkat sampai fermentasi hari ke-15, tetapi kemudian menurun dengan makin lama waktu fermentasi. Kadar alkohol, total gula dan total padatan terlarut (TPT) menurun selama fermentasi. Kerapatan sel mikroba $\left(\mathrm{OD}_{660}\right)$ meningkat sampai fermentasi hari ke-10, tetapi kemudian menurun dengan makin lama waktu fermentasi.

Fermentasi alami secara aerob untuk produksi asam asetat dimungkinkan karena cuka kakao sebagai hasil samping fermentasi biji kakao, diantaranya telah mengandung asam asetat, alkohol dan gula (Afoakwa dkk., 2013). Selain itu mikroba awal seperti yeast dan bakteri asam asetat juga sudah terinokulasi dalam cairan pulpa. Hal tersebut dimungkinkan karena selama fermentasi biji kakao terjadi perombakan gula pulpa, yang menyebabkan pulpa menjadi hancur dan membentuk cairan yang menetes keluar tumpukan biji. Mekanisme tersebut terjadi karena kandungan gula yang relatif tinggi, $\mathrm{pH}$ rendah dan suplai oksigen yang rendah pada tumpukan biji selama tahap awal fermentasi menyebabkan yeast mampu berkembang dengan baik. Menurut Schwan (1998), Ardhana dan Fleet (2003), Takrama dkk. (2015), aktivitas utama yeast pada pulpa biji kakao adalah: (a) disimilasi sukrosa, glukosa dan fruktosa menjadi etanol dan $\mathrm{CO}_{2}$, (b) pemecahan pektin dalam pulpa, dan (c) metabolisme asam-asam organik (asam sitrat) yang terdapat dalam jumlah relatif banyak pada pulpa biji kakao. Selanjutnya pertumbuhan bakteri asam asetat menjadi dominan karena suhu makin naik yang mencapai $45-50{ }^{\circ} \mathrm{C}$ dan adanya aerasi karena proses pengadukan. Proses-proses tersebut berlangsung pada 24-48 jam di awal fermentasi biji kakao.

Kondisi demikian menyebabkan substrat cairan pulpa hasil samping fermentasi biji kakao selama 1-3 hari telah mengandung asam asetat $0,87 \%$, alkohol $1,6 \%$, total gula $5,59 \%$, TPT $6,50^{\circ}$ Brix, dan kerapatan sel pada $\mathrm{OD}_{660}$ sebesar $0,173 \times 10^{1}$ (Tabel 3). Selanjutnya dengan fermentasi lanjutan tanpa inokulum (alami) secara aerob, alkohol dirombak oleh bakteri menjadi asam asetat, termasuk di dalamnya terjadi perombakan gula yang ditunjukkan oleh turunnya kadar total gula serta berkurangnya TPT selama fermentasi. Aktivitas perombakan tersebut berlangsung oleh aktivitas mikroba alami, yang terdapat dalam cairan pulpa, seperti dilaporkan oleh H-Kittikun dkk., (2004), bahwa pada tahap awal fermentasi biji kakao ditemukan total mikroba sebesar $1,40 \times 10^{3} \mathrm{CFU} / \mathrm{g}$, yeast $2,11 \times 10^{5} \mathrm{CFU} / \mathrm{g}$, bakteri asam asetat $2.85 \times 10^{3} \mathrm{CFU} / \mathrm{g}$ dan bakteri asam laktat $1,85 \times 10^{3} \mathrm{CFU} / \mathrm{g}$. Keberadaan mikrobia alami tersebut dapat ditunjukkan dari perkembangan kerapatan sel mikroba $\left(\mathrm{OD}_{660}\right)$ yang meningkat sampai hari ke-10, tetapi kemudian turun lagi.

\section{Produksi Asam Asetat dari Beberapa Metode Fermentasi Lanjutan}

Berdasarkan uraian di atas, dapat dikemukakan bahwa produksi cuka kakao potensial dihasilkan pada metode fermentasi 2 tahap dengan penambahan gula cenderung $6 \%$ dan metode fermentasi 1 tahap dengan penambahan alkohol $10 \%$. Selanjutnya kedua metode fermentasi lanjutan tersebut dibandingkan juga dengan metode fermentasi alami. 


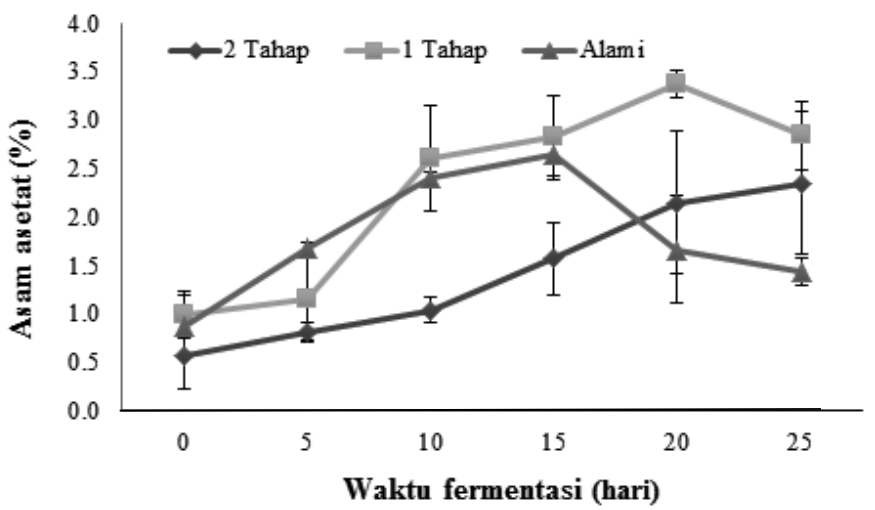

Gambar 1. Perubahan kadar asam asetat cuka kakao selama fermentasi pada beberapa metode fermentasi lanjutan

Perubahan kadar asam asetat cuka kakao selama fermentasi pada beberapa metode fermentasi lanjutan disajikan pada Gambar 1.

Dari Gambar 1 dapat diketahui bahwa kadar asam asetat pada metode fermentasi 2 tahap dengan penambahan gula $6 \%$ meningkat selama fermentasi dan mencapai maksimal pada hari ke-25 (2,35\%); pada metode fermentasi 1 tahap dengan penambahan alkohol $10 \%$ juga meningkat selama fermentasi dan mencapai maksimal pada hari ke-20 (3,37 $\%$ ); sedangkan pada metode fermentasi alami meningkat dan mencapai maksimal pada hari ke-15 (2,65\%), tetapi kemudian menurun. Dengan demikian dapat dikemukankan bahwa metode fermentasi 1 tahap dengan penambahan alkohol $10 \%$ menggunakan inokulum Acetobacter aceti dengan waktu fermentasi 20 hari merupakan metode yang paling optimal untuk produksi cuka kakao dari substrat cairan pulpa hasil samping pengolahan kakao. Hasil tersebut lebih tinggi dibandingkan dengan hasil survey oleh Kozaki dkk. (1998) pada proses pembuatan asam asetat secara tradisional di Indonesia dan Philipina, yaitu sekitar $2 \%$.

\section{KESIMPULAN}

Karakteristik cuka kakao dan $\mathrm{OD}_{660}$ cairan pulpa dipengaruhi oleh perlakuan penambahan gula dan lama fermentasi serta interaksinya pada metode fermentasi alkohol dan asam asetat (2 tahap); dan dipengaruhi oleh perlakuan penambahan alkohol dan lama fermentasi serta interaksinya pada metode fermentasi asam asetat (1 tahap), serta dipengaruhi oleh perlakuan lama fermentasi pada metode fermentasi tanpa inokulum (alami). Cuka kakao dengan kadar asam asetat tertinggi masing-masing dihasilkan pada fermentasi 2 tahap dengan penambahan gula cenderung 6 $\%$ dalam waktu 25 hari (2,35\%); fermentasi 1 tahap dengan penambahan alkohol $10 \%$ dalam waktu 20 hari (3,37\%); dan fermentasi alami dalam waktu 15 hari (2,65\%); dengan demikian metode fermentasi 1 tahap dengan penambahan alkohol $10 \%$ menggunakan inokulum Acetobacter aceti dalam waktu 20 hari merupakan metode fermentasi lanjutan yang paling optimal untuk produksi cuka kakao.

\section{UCAPAN TERIMA KASIH}

Penulis mengucapkan banyak terimakasih kepada DP2M Ditjen Dikti, Kementerian Pendidikan dan Kebudayaan RI yang telah membiayai penelitian ini melalui skim Hibah Kompetensi, dengan Surat Perjanjian Penugasan Pelaksanaan Penelitian Nomor: 183/UN14.2/PNL.01.03.00/2015 tanggal 3 Maret 2015.

\section{DAFTAR PUSTAKA}

Afoakwa, E.O., Kongor, J.E., Takrama, J.F. dan Budu, A.S. (2013). Changes in acidification, sugars and mineral composition of cocoa pulp during fermentation of pulp pre-conditioned cocoa (Theobroma cacao) beans. International Food Research Journal 20(3): 1215-1222.

Alamsyah, T.S. (1991). Peranan fermentasi dalam pengolahan biji kakao kering. Suatu Tinjauan. Berita Perkebunan 1(2) : 97-103

Ardhana, M.M. dan Fleet, G.H. (2003). The microbial ecology of cocoa bean fermentations in Indonesia. International Journal of Food Microbiology 86: 87-99.

Baharuddin, Syahidah dan Yatni, N. (2008). Penentuan mutu cuka nira aren (Arenga pinnata) berdasarkan SNI 014371-1996. Jurnal Perennial 5(1): 31-35.

Barlina, R., dan Lay, A. (1994). Pengolahan nira kelapa untuk produk fermentasi nata de coco, alkohol dan asam cuka. Jurnal Penelitian Kelapa 7: 21-23.

Daulay, D. dan Rahman, A. (1992). Teknologi Fermentasi Sayur dan Buah-Buahan. Pusat Antar Universitas Pangan dan Gizi Institut Pertanian Bogor, Bogor.

Dias, D.R., Schwan, R.F., Freire, E.S., dan Serôdio, R.D.S. (2007). Elaboration of a fruit winefrom cocoa (Theobroma cacao L.) pulp. International Journal of Food Science and Technology 42(3): 319-329.

Duarte, W.F., Dias, D.R., Oliveira, J.M., Teixeira, J.A., de Almeida e Silva, J.B., dan Schwan, R.F. (2010). Characterization of different fruit wines made from cacao, cupuassu, gabiroba, jaboticaba and umbu. $L W T$ Food Science and Technology 43(10): 1564-1572.

Efendi, M.S. 2002. Kinetika fermentasi asam asetat (vinegar) oleh bakteri Acetobacter aceti $\mathrm{B}_{127}$ dari etanol hasil 
fermentasi limbah cair pulp kakao. Jurnal Teknologi dan Industri Pangan 13(2): 125 - 135.

Ganda-Putra, G.P., Harijono, Susanto, T., Kuamalaningsih, S., dan Aulani'am (2008). Optimasi kondisi depolimerisasi pulp biji kakao oleh enzim poligalakturonase endojinus. Jurnal Teknik Industri FT-UMM 9(1): 24-34.

Ganda-Putra, G.P., dan Wartini, N.M. (2014a). Kajian kuantitas dan karakteristikcairan pulpa hasil samping fermentasi biji kakao menggunakan wadah sistem "termos" sebagai bahan baku asam asetat. Media Ilmiah Teknologi Pangan 1(1): 31-40.

Ganda-Putra, G.P. dan Wartini, N.M.(2014b). Karakteristik cairan pulpa hasil samping fermentasi biji kakao yang ditambahkan ragi tape untuk produksi cuka makan. Prosiding Seminar Nasional Hasil Penelitian dan Pengabdian Masyarakat, Denpasar, Unmas Press, Hal. 334-339.

Ganda-Putra, G.P., Wartini, N.M. dan Ina, P.T. (2015). Pengaruh suhu dan waktu distilasi cairan pulpa hasil samping fermentasi biji kakao terhadap karakteristik distilat cuka fermentasi. Media Ilmiah Teknologi Pangan 2(2): 55-64.

Hardoyo, Tjahjono, A.E., Primarini, D., Hartono dan Musa (2007). Kondisi optimum fermentasi asam asetat menggunakan Acetobacter aceti $\mathrm{B}_{166}$. Jurnal Sains Matematika dan Ilmu Pengetahuan Alam, Universitas Lampung, Edisi Khusus 13(1): 17-20.

Herawati, H. (2008). Penentuan umur simpan produk pangan. Jurnal Litbang Pertanian, 27 (4): 124-130.

Hidayat, N., Nurika, I., dan Latifah, U. (1997). Peranan alkohol dan kecepatan aerasi pada fermentasi asam asetat dari air kelapa. Habitat 8(99): 44-46.

Hotmaka, O dan Ebner, H. (1995). Vinegar by submerged oxidative fermentation. Industrial and Engineering Chemistry 51: 1279-1280.

H-Kittikun, A., K. Intrapichet, N. Ratchasima, P. Prasertsan and S. Jitbunjerdkul, 2004. Preparation of starter cultures for industrial fermentation of cocoa I. Microbial changes during cocoa bean fermentation. http://www. clib.psu.ac.th/acad_41/haran5.htm. [18 Maret 2004].
Kozaki, M., Lino, H. Matsumoto, T. Dizon, E.I., Rahayu, K. dan Sanchez, P.C. (1998). Studies on the acid-producing bacteria of traditional vinegarsfrom the Philippinnes and Indonesia. Proceeding International Conference on Asian Network on Microbial Research, Gadjah Mada University, Yogyakarta, Indonesia. Hal. 451-464.

Kwartiningsih, E. dan Mulyati, N.S. (2005). Fermentasi sari buah nanas menjadi vinegar. EKUILIBRIUM 4(1): 8-12.

Lu, S., Lee, dan Chen, H. (1999). A Thermotolerant and high acetic acid-producing bacterium Acetobacter sp. I14-2. Journal of Applied Microbiology 86(1): 55-62.

Puerari, C., Magalhães, K.T., and Schwan, R.F. (2012). New cocoa pulp-based kefir beverages: Microbiological, chemical composition andsensory analysis. Food Research International 48: 634-640.

Rahman, A. (1992). Teknologi Fermentasi. Penerbit Arcan, Jakarta.

Reed, G. and Nagodawithana, T.W. (1991). Yeast Technology. Van Nostrand Reinhold Publisher, New York.

Schwan, R.F. (1998). Cocoa fermentations conducted with a defined microbial cocktail inoculum. Applied of Environ Microbiology 64(4): 1477-1483.

Schwan, R. F. dan Wheals, A. E. (2004). The microbiology of cocoa fermentation and its role in chocolate quality. Critical Reviews in Food Science and Nutrition, 44(4): 205-221.

SNI 01-4371-(1996). Standar Nasional Indonesia Cuka Fermentasi. Dewan Standardisasi Nasional-DSN, Jakarta.

Takrama, J. F., Kumi, W. O., Otoo, G., Addo, K. dan Camu, N. (2015). Optimization of cocoa pulp juice fermentation with yeast starter cultures of cocoa heap fermentations. Journal of Agricultural Science and Food Technology 1(3): 22-33.

Zubaidah, E. (2010). Kajian perbedaan kondisi fermentasi alkohol dan konsentrasi inokulum pada pembuatan cuka salak (Salacca zalacca). Jurnal Teknologi Pertanian 11(2): 94-100. 